\title{
State of Democracy at service of the Nation
}

\author{
Jatindra Kumar Behera \\ Ganges Jute Private Limited. West Bengal, India
}

\begin{abstract}
The epitomization of the presentation is prevailing political, Soco-economic scenario in India and how scientific, communication revolution notwithstanding and despite well defined national management system in place, India is continuing as a super poor with one third of world's poor population living in India. Essence is that custodians of democracy must have highest standard of probity \& integrity which is just absent and has yielded place to individual need \& greed for which India is now in complete siege from within with remote hope of restoration of value system and national welfare which is defined by deliverance of well affordable meaningful living to the common man. With India at such a crossroad, sincere most and committed Indians very very minority \& miniscule in number, hardly there is any countable figure among those in charge of governances the country, have been left to dwell in wishful thinking, lecturing to audience who listen for listening sake and cracking head at such critical and irrecoverable decay of democratic model of administration mindlessly conducted by its selected, elected \& even self appointed guardians.
\end{abstract}

Keywords: Democratic-model, Epitomization, Irrecoverable, Notwithstanding, Probity.

\section{Introduction}

As a concerned Indian committed to the cause of meaninglessly suffering common citizen who form the bottom of the pyramid, I always discuss with any one whoever patiently listens to me regarding unprovoked stampede on democracy by its custodians and keep myself engrossed in thinking whether there can be any turnaround.

\section{Text of Presentation.}

\section{State of Democracy at service of the Nation}

Let me make the beginning with top management Guru Professor Peter F.Druckker's observation - " It is duty of the management to convert a crowd into an organization and Human activities into development". In view of its very high labor intensively i.e. around 10,000 hands at rate of 40 Hands / M.T. in our both units, Peter Druckker's above concept is applicable in more than many senses to jute Industry than to any other sector.

While functioning in line with process of planning, organizing, directing, controlling, managing activities appropriately utilizing available resources, methodologies, largest no. of illiterate, semiliterate, unskilled, semiskilled \& skilled work force working under inhospitable conditions you have seen remains most difficult task to handle. These unionized and highly organized work force are potent force in creating various pressures on management, even disrupt the working of industry. Hence technical training is regularly imparted through agencies like Institute of Jute Technology, Indian Jute Industries Research Association, Individual experts and counselling individually \& in group to diagonise the labour issues and timely resolve these remain most important task of HR section in consultation with the authorities. TATA Iron and Steel Company with annual turnover of Rs. 5000 Crores of Rupees employs 5000 man force and total Jute Industry with its annual turnover of Rs. 6500 Crores of Rupees provides employment directly to 2.4 Lakhs work force which is almost 37 times as compared to former. Other employments are 40 Lakhs families in farm sector for production of Jute, 1.5 Lakhs in ancillary sector.

Therefore we all must be thankful to Jute Mill owners not because I am working here but because these entrepreneurs with so low turnover of Rs. 6500 Crores are catering to so huge employment doing a lots of painstaking activities amounting almost to firefighting. It must be dutifully noted that no well known industrial house is into Jute Sector (Excepting Birlas, even their mill is at verge of uncertainty).

Having said these; I must dutifully talk about Six Jute Mills under NJMC (National Jute manufacturer's Corporation), Govt. of India performing abysmally, now non-functional \& money spent on it without any return is a sheer drainage on National exchequer. I think from this point; the focus should be expanded to broader and larger issues with various management activities involving greater national concern \& objectives. It would not be out of place to mention here that Public Sector Industries created by late $\&$ first Priminister Pandit Nehru to enjoy commanding height of Indian economy now act as drag \& drain on it whether we call them by names of Navaratna, Miniratna \& so on so forth.

This year I had privilege of attending three seminars in Kolkata graced by three leading lights from different walks of life. First one was IIM-kolkata \& IIM-Mumbai sponsored Guruspeak where Dr.R.Venkat 
Ramaswamy, Hallman fellow of Business electronics and professor of marketing at Ross School of Business, Michigan university a thinker, electic scholar presented a day long workshop in theory of Co-creation which essentially means wholesome participation of all stake holders in functioning of any Industry / business. His book "Future of competition" co-authored along with his mentor Prof. C K Prahalled contains major deliberation in this issues and in coming years for successful companies Co-creation is going to be like oxygen. During interaction as to what is takeaway from the workshop, I told the distinguished professor that while learning a lot I am not sure as to what should be my takeaway, because as I depart the venue, I am not going to visualize any change in human misery around us, even I may not do something new from tomorrow which would remarkably improve my company's performance. By saying so, I do not mean nor can I at all venture to undermine learned professor's deliberation, all I mean is what such wealth of knowledge and articulation notwithstanding, disparities of inexplicable magnitudes continue unbridled.

$2^{\text {nd }}$ one was an event organized by Round Table India on "opportunities and challenges ahead of India in $21^{s t}$ Century" graced by colourful Dr. Sashi Tharoor. Spell binding orator, author, international bureaucrat as former un-under secy. General for international affairs and public relations at U.N.O. In his grandeloquent deliberation, Dr. Tharoor talked about astounding scientific, technological development, more particularly unprecedented communication revolution since liberalization. While hailing India as a super Power for its third largest economy (Due to Tsunami and Nuclear disasters in Japan), $3^{\text {rd }}$ largest scientific and technological power base, he minced no words in describing India simultaneously as a super poor meaning that trickle down effect of development not reaching the ultimate recipient. He further hailed the largest number of youth force entering into various walks of life as the greatest asset in changing the shape of India. I have every skepticism that prevalent Indian Socio-economic \& political scenario in stead of being revamped by the Youth will rather modulate them to mingle into the murky mainstream.

In interaction, I had asked about the debate "Benevolent dictatorship Vs exploitative democracy" hosted by famous St. Xavier's Collage and participated by distinguished personalities like Sri Arun Shourie, Mr. Mani Shankar Iyer among others. Is this nation in genuine need of such a change? But all the tall personalities I have spoken have hailed democracy with all its vices against dictatorship with all its virtues. Even I had broached about Sri Subshas Chandra Bose as benevolent dictator and that if he would have headed administration in India for at least Ten years after independence, scenario would have been different today. But what storms my brain the most is that mind boggling corruption plaguing our system, gross inequity of wealth distribution - corporate sector executive earning multi figure salary, politician \& bureaucrats mindlessly plundering state exchequer, the Planning Commission decides Rs. 26 a day / head in rural areas \& Rs. 36 a day / head for urban areas is indeed a monumental shame and politicians across the party devide pillorying Planning Commission deputy Chairman Dr. Montek Singh Ahlualia without for a moment realizing that it is their gross misdemeanor, gross departure from constitutionally sanctioned living and function has wrought this havoc on the nation and what Dr. Montek Singh Ahlualia placed before parliament was exactly mirror image of the way our system functions in. In fact, a statesman is a politician who puts himself at the services of the nation, but a politician is a statesman who puts the whole nation at his service and this is exactly the scenario we are now confronted with. Oxford Poverty \& Human development initiative \& Dr. Arjun Sengupta report on $70-80 \%$ of Indian earning between Rs. 25 to Rs. 30 a day. How can they have purchasing power?

$3^{\text {rd }}$ event organized by the Telegraph entitled "Civil society Vs State its role \& responsibility in democracy" deliberated upon by Padma Bibhusan award winning sociologist, Chairman, Centre for Studies in Social Sciences, Prof. Emritus, Delhi School of economics \& Member, Primiminister's National Knowledge Commission, Dr. Andre Betelli. He was like others, a firm believer in democracy with all its pitfalls, further believed in resolution to mounting Socio-economic problems in society within frame work of constitution \& that too through articulation within Indian parliament. The same Padma Bibhusan awardee further said our parliament transacts no business eventhough its spends Rs. 37000 per minute or Rs. 1.7 Coror Per day on 2004 estimates. Various cabinet committees do the job. In recent past brilliant articulation by Sri Arun Jaitely in impeachment of Calcutta High Court Judge Justice Soumitra Sen is a reminder of Indian parliament's Glorious past.

In any interaction, I expressed my introspection and belief that at a time when politicians and Govt. executives instead of behaving constitutionally, have put the nation at their services - rise of civil society spearheaded currently by Sri Anna Hazare needs well judged, guarded support in raising a brave fight against corruption. It is definitely a defining moment in nation's life and we must define the moment now that it has come along or the moment will as usual define us.

American president J.F. Kenedy had said "The mankind must put an end to war or the war will an end to the mankind". Drawing an analogy, it can be pertinently argued "India must put an end to corruption or corruption will put an end to India" I know a student of IIM having his internship in CPI (M) party head Quarters under veteran Mr. Sitaram Yechury and I believe, time is not far off some management graduate may opt for Internship in civil society. 
Delivering his valedictory address at $125^{\text {th }}$ Birth Anniversary of Great educationist Sir Asutosh Mukherjee at Calcutta University, the late Sri N.A. Palkivala, a great Scholar and illustrious son of mother India had told, "Our value agnostic educational system is content in Churning out moral idiots \& ethnical illiterates". Another observation by many sceptics that liberalization while ushering in astounding development has unbridgably widened the rich - poor divide.

While holding Sri N.A.Palkivala with highest regard for all his noble qualities, concrete granite integrity and also somewhat aware of drawbacks of liberalization, I venture to argue that these observations amount to bad workman quarreling with his tools. No education whether Arts, Science, Commerce, Engg. Or Management has ever taught us to be dishonest, unethical and rather it is our devilish need \& greed which powerfully propels us to abuse our position, instrument / system meant for national development. Education system has nothing to do with it.

The issue between what we do and what we are capable of doing can solve our problems. A critical balance has to be struck between saying, "Ends gets vitiated if means are bad \& ends justify means", while discharging our duties.

Now I like to focus on what three leading management gurus have worked in this context.

First one is the book by coveted management Guru Dr. C.K Prahallad "The future at Buttem of pyramideradicating poverty through profits". Its central idea is simply that 70 to $75 \%$ of Indian in poor income bracket \& constituting buttom of pyramid must be provided with meaning of life in terms of constitutionally granted right to Education, Healthcare, average living \& this alone can take care of various forms as Socio-economic discomforts.

Second book "Great Indian Dream" by Dr. Arindam Choudhary of IIPM launched on eve of American president Bill Clinton's visit to India in 2001 advocates India can beat \& outwit USA economically. Even Dr. Choudhary with great enthusiasm held seminars in all our cities, prolifically argued in favaur of his contention. Public memory is proverbially short; they get temporarily charged \& then forget. I can draw parallel between Dr. Choudhary's energetic argument \& Dr. Subramaniam Swamy's saying "Aspire to go to sky, you can reach the tree top".

$3^{\text {rd }}$ book by motivating speaker Shiv Khera "Freedom is not free" is probably self explanatory from its title. During his present visit to Kolkata on $12^{\text {th }}$ May 2012 for event Fulcrum 2012, Mr. Khera was asked that people get temporarily changed while listening to him, forget and get back to their ownself once the event is over. Mr. Khera told that if people practise continuously for 31 days what they listen, then it will be a normal activity from $32^{\text {nd }}$ day. It is really an issue that provides impetus for development and need to be experimented seriously.

We are now living in an India where democracy (which according to writer Dr. Ramachandra Guha is $45 \%$ effective) has come to stay for good, corruption at its peak whatever be its reason has come to stay for good also and in absence of strong umbrella leadership, coalition politics is taking toll on democracy day in \& day out. The scenario can be aptly described in what Mr. N.A.Palkivala once observed "We have too much of judiciary with too little of justice, too much of Administration with too little of governance \& too much Of control with too little of welfare". Can we term it as unity in diversity. That will be ultimate dishonour to spirit of constitution.

Finally \& concludingly I turn to greatest Management Guru of all times, father of Nation Mahatma Gandhi who said "Recitation of Gita will be no avail if it does not help in building the character." This self explaining epitomisation of all human activities on earth must guide us in discharging our duties. His saying be the change to see the change you want is truly eternal.

One thing more I must say effective leadership is not about making good speeches or being liked. Leadership is identified by results, not attributes. Qualities like making good speeches or being liked can only make your performance more $\&$ more colourful.

Once more I welcome Students \& Faculties of S.P.Jain Institute of Management \& Research, Mumbai. Set up in 1981 as an initiative of Bharatiya Vidya Bhavan, opened by the then towering would leader Mrs. Margaret Thatcher, Prime-Minister of Great Britain, The Institute is autonomous, unaffiliated \& self financed. It has grown from strength to strength in stature and is producing management Graduates who are holding coveted positions in various sectors \& my advice to you all is to look at human being with humane eye which alone can contribute in ushering an India of our dream. Novel project of your institution like internship with NGOS in rural areas will definitely help in developing integral citizenship.

Mother India has a lot to expect from us and let us comit ourselves to work in that direction.

\section{Conclusion}

As argued in the abstract, restoration of highest order of probity, integrity \& transparency (All presumably illusory at the moment) among the custodians of democracy is of utmost importance. This in turn will lead to semblance of ethics in business management, national governance and will gradually improve quality of life at buttom line. Role of civil society in truest sense of the term (There is absolute sceptcism 
whether it can at all happen) in acting as a perfect watchdog needs to be extended well judged \& guarded support to invoke the sleepant spirit in the common people. Finally adopting practices and preaching of Mahatma Gandhi in whatever measures possible must have to be thought, acted upon and all these measures in combination can act as a deterrent in tearing into human monstrosity on human being.

\section{Acknowledgements}

1) Presentation of Dr.R.V. Ramswany, Hall man fellow of business electronics \& prof. of marketing at Ross School of Business on Theory of Co-creation at Kolkata.

2) Deliberation by Dr. Sashi Tharor on Challenges \& opportunities for India in $21^{\text {st }}$ Century at Kolkata.

3) Deliberation by Dr. Andre Betelli, Padma Bhusan award winning sociologist on Role \& responsibility of civil society in democracy in Kolkata.

[1]. Quotes of Management Guru Dr. Peter F.Drucker.

\section{References}

[2]. Quotes of late constitutional baron in India Mr. Nani Palkivala

[3]. Quotes of Mahatma Gandhi

[4]. Quotes of American president John. F.Kenedy \& Indian Economist turned politician Dr. Subramaniam Swamy.

[5]. Books by Dr. C.K.Prahallad, Dr. Arindam Choudhury of IIPM \& motivating Speaker Mr. Shiv Khera.

(The author is The General Manager, Ganges Jute Pvt. Ltd. And the article was the text of his presentation to students and faculty of S.P.Jain Institute of Management and Research, Mumbai during their visit to industry on $12^{\text {th }}$ June 2012 . The author can be contacted with mobile no. +919836572732 and Email Id:jkbehera59@gmail.com) 